\title{
Oksitosin Nöronlarında Kainat Reseptör Alt Birimlerinin Sentezi: İmmünohistokimyasal Çalışma
}

\author{
Zehra MİNBAY, Özhan EYİGÖR
}

Bursa Uludağ Üniversitesi Tıp Fakültesi, Histoloji ve Embriyoloji Anabilim Dalı, Bursa.

\begin{abstract}
ÖZET
Oksitosin nöronları, gebe dişide doğumu başlatan ve sürdüren, ayrıca meme bezlerinden süt enjeksiyonunu sağlayan nöroendokrin mekanizmanın en önemli kısmını oluștururlar. Hipotalamik supraoptik (SON) ve paraventriküler (PVN) çekirdeklerde yerleșik olan bu nöronların regülasyonunda merkezi sinir sisteminde yer alan glutamaterjik sistemin önemli rolü olduğu bilinmektedir. Glutamat etkisini hücre membranları üzerinde bulunan reseptörlerine bağlanıp onları aktive ederek gösterir. Bu reseptörlerin üç ayrı alt grubundan biri olan kainat reseptörlerine ait alt birim proteinlerinin oksitosin nöronlarınca sentezlendiğine dair bilgi henüz raporlanmamıştır. Bu çalışmada, oksitosin nöronlarında kainat reseptör alt birimlerinin (GluK1, GluK2, GluK3, GluK5) eksprese edilip edilmediğinin belirlenmesi amaçlandı. Bu amaçla dişi sıçan hipotalamusunda oksitosin ve reseptör ko-lokalizasyonunun belirlenmesinde ikili immünofloresan işaretleme tekniği kullanıldı. Bu boyamaların sonucunda, SON ve PVN'deki oksitosin nöronlarının sayıca çok büyük bir kısmının aynı zamanda GluK5 proteini sentezledikleri belirlendi. Her iki çekirdekte yer alan tüm oksitosin nöronlarının yaklaşık yarısının GluK2 sentezlendiği görüldü. Preparatların incelenmesi sonucunda oksitosin nöronlarında GluK1 ve GluK3 proteinlerinin ekspresyonu izlenmedi. Sonuç olarak çalışmamızda oksitosin nöronlarının fonksiyonel reseptör kanalı oluşturabilecek kainat reseptör alt birimleri eksprese ettiklerinin belirlenmesi, endojen glutamatın oksitosin nöronları üzerindeki etkilerini bu reseptörlere bağlanarak gerçekleştirebileceğini düşündürmektedir. Oksitosin nöronlarında kainat reseptör alt birimlerinin ekspresyonun gösterilmesi bu konudaki literatüre önemli katkılar sağlayacağı ön görüsündeyiz. Gelecekte yapılacak olan fizyolojik ve farmakolojik çalışmalarla veya transgenik hayvanlardan elde edilebilecek bulgulara çalışmamızda elde ettiğimiz sonuçlar eklendiğinde, kainat reseptörlerinin oksitosin sentez ve salgılama mekanizmasındaki rolü açıklığa kavuşacaktır.
\end{abstract}

Anahtar Kelimeler: Oksitosin. Glutamat. Kainat reseptörleri. GluK2. GluK5. İmmünohistokimya.

Synthesis of Kainate Receptor Subunits in Oxytocin Neurons: An Immunohistochemical Study

\begin{abstract}
Oxytocin neurons are the most important part of the neuroendocrine mechanism which starts and maintains the parturition as well as the milk ejection. These neurons are localized in the hypothalamic supraoptic (SON) and paraventricular (PVN) nuclei and glutamatergic system plays an important role in the regulation of these neurons in the central nervous system. Glutamate exerts its effects by binding and activating its receptors on the plasma membrane. There is a lack of knowledge in the literature on the synthesis of kainate receptors, as one of the glutamatergic subfamilies, by oxytocin neurons. In this study the aim is to determine if the kainate receptor subunits (GluK1, GluK2, GluK3, GluK5) were expressed in oxytocin neurons. For this purpose, double immunofluorescence labeling technique was employed in order to assess the co-localization of oxytocin with respective receptor in the female rat hypothalamus. The results of this staining showed that almost the vast majority of oxytocin neurons were immuno-reactive for GluK5 protein in both SON and PVN. It was determined that almost half of the oxytocin neurons in both of the nuclei synthesize GluK2. Analyses of the preparations revealed no expression of GluK1 and GluK3 proteins in the oxytocin neurons. As a result, the determination of the oxytocin neurons can synthesize kainate receptor subunits which can form functional kainate receptor channels suggests that the endogenous glutamate can exert its effects on oxytocin neurons by binding these receptors. We anticipate that showing the oxytocin neurons express kainate receptor subunits would be an important addition to the literature. The future physiological and/or pharmacological studies as well as the possible findings from the transgenic animals would enlighten the role of kainate receptors in the regulation of oxytocin synthesis and/or releasing mechanism.
\end{abstract}

Key Words: Oxytocin. Glutamate. Kainate receptors. GluK2. GluK5. Immunohistochemistry.

Geliş Tarihi: 09.Kasım.2020

Kabul Tarihi: 03.Aralık.2020

Dr. Özhan EYIGÖR

Bursa Uludağ Üniversitesi Tıp Fakültesi, Histoloji ve Embriyoloji Anabilim Dalı, Bursa.

Tel: 02242954065

E-posta: oeyigor@uludag.edu.tr

Yazarların ORCID ID Bilgisi:

Zehra MiNBAY: 0000-0001-5757-8450

Özhan EYIGÖR: 0000-0003-3463-7483
Oksitosin nöronları, gebe dişide doğumu başlatan, sürdüren $^{1,2}$ ve meme bezlerinden süt ejeksiyonunu sağlayan $^{3}$ nöroendokrin mekanizmanın en önemli bölümünü oluşturur. Somaları hipotalamusta paraventriküler ve supraoptik çekirdeklerde yerleşik olan bu nöronların aksonları nörohipofizde sonlanır ve oksitosin burada hipofizer dolaşım sistemine salgılanır ${ }^{4,5}$. Oksitosin nöronlarının regülasyonunda periferden gelen uyarıcı sinyaller kadar merkezi sinir sisteminde 


\section{Z. Minbay ve Ö. Eyigör}

bulunan bazı nörotransmitter sistemlerin de önemli rolü olduğu bilinmektedir 6 . Noradrenerjik ${ }^{7}$, histaminerjik $^{8}$ ve glutamaterjik ${ }^{9-13}$ ve gama aminobütirik asit (GABA) içeren sistemler ${ }^{14}$, oksitosin salgılayan magnosellüler nöronların regülasyonunda yer alan en önemli sistemlerdir. Glutamaterjik sistemin, hipotalamus-hipofiz-gonadal, hipotalamus-hipofiz-adrenal ve hipotalamo-nörohipofizer sistemler gibi farklı nöroendokrin döngülerin çalışmasında eksitasyon yapıcı çok önemli roller aldığı, son yıllarda yapılan çalışmalarda gösterilmiștir ${ }^{12,15,16}$.

Glutamat etkisini hücre membranları üzerinde bulunan reseptörlerine bağlanıp onları aktive ederek gösterir. Glutamat reseptörleri iki grupta toplanmıştır. Metabotropik glutamat reseptörleri yedi transmembran parçası olan G-proteine bağlı reseptörlerden oluşurken, iyonotropik reseptörler iyonlara özgül reseptör kanalları oluştururlar $^{6,17}$. İyonotropik glutamat reseptörleri farmakolojik özelliklerine göre üç alt ailede toplanmıştır ${ }^{6}$. N-metil D-aspartat (NMDA, GluN1-3) reseptörleri genel olarak, alfa-amino-3-hidroksi-5-metil- izoksazol-propionik asit (AMPA, GluA1-4) ve kainat reseptörlerinden (GluK1-5) ayrı olarak değerlendirilmektedir ve bu nedenle AMPA ve kainat reseptörleri "nonNMDA" reseptörleri olarak da bilinmektedir ${ }^{18}$.

Elektron mikroskopik çalışmalarda ${ }^{19}$ oksitosin nöronları üzerinde glutamat içeren sinapsların varlığının gösterilmesi, glutamaterjik sistemin oksitosin sentezi ve salgılanmasında rol aldığını düşündürmektedir. Bunlara ek olarak elektrofizyolojik ve histolojik metotların kullanıldığı çalışmalarda glutamat ${ }^{20}$ ve glutamat reseptör agonistlerinin magnosellüler oksitosin nöronlarını uyarabildiğ $\mathrm{i}^{21}$ ve depolarize edebildiğ $\mathrm{i}^{22}$; farmakolojik çalışmalarda verilen spesifik agonistin oksitosin salınımını arttırdığı belirlenmiștir ${ }^{23,24}$. Glutamat reseptör tipine özgül antagonistlerin kullanımı ise glutamatın etkilerini bloke edebilmektedir ${ }^{21,25-28}$. Söz konusu bu çalışmaların çoğu glutamat reseptörlerinin üç alt grubundan özellikle NMDA ve AMPA reseptör etkileri üzerine yoğunlaşmıșsa da üçüncü grup olan kainat reseptörlerinin de bu mekanizma içinde yer aldığı belirlenmiştiri ${ }^{26,29,30}$. Histolojik çalışmalarda $\mathrm{AMPA}^{31}$ ve $\mathrm{NMDA}^{32}$ reseptörlerinin bazı alt birimlerinin oksitosin nöronlarınca sentezlendiği gösterilmiștir. Kainat reseptör alt birimlerinin oksitosin nöronlarında eksprese edildiğini gösteren bir çalışma literatürde mevcut değildir. Bu çalışmada oksitosin nöronlarında eksprese edilen kainat reseptör alt birimlerinin immünohistokimyasal metotlarla belirlenmesi amaçlanmıștır.

\section{Gereç ve Yöntem}

Çalışma, Üniversitemiz Hayvan Bakım ve Kullanım Komitesi'nin 19.04.2005/1 sayılı kararı ile etik yönden uygun bulunarak yapıldı. Çalışmada, erişkin (60-
90 günlük) Sprague Dawley cinsi dişi sıçanlar kullanıldı. Sıçanların bulunduğu ortam 1 sisı $20-24^{\circ} \mathrm{C}^{\prime}$ de sabit tutulup, 12 saat aydınlık ve 12 saat karanlık (07.00-19.00 arası aydınlık) döngüsü uygulandı ve hayvanlar ad libitum olarak su ve yemle beslendi. Denekler derin eter anestezisi altında, $0,13 \mathrm{M}$ fosfat tamponu $(\mathrm{pH} 7,4)$ ile hazırlanan \%2 paraformaldehit ile perfüzyon fiksasyonu yöntemi ile sakrifiye edildi. Perfüzyon fiksasyon öncesi deneklerin göğüs kafesi açıldı ve kalp apeksinden uygulanan kateter aorta içine yerleştirilerek sabitlendi. Solüsyonlar damar içine uygun basinca ayarlanan perfüzyon pompası ile verildi. Fiksasyon öncesi deneğin dolaşım sistemi fizyolojik tuzlu su ile temizlendi $(50 \mathrm{ml})$. Denek başına $400 \mathrm{ml}$ fiksatif solüsyonu kullanıldı. Fiksasyon ișlemi sonrasında deneklerin kraniumları açılarak beyinler çıkartıldı. Çıkartılan beyinlere aynı fiksatif içerisinde gece boyu post-fiksasyon uygulandi. Ertesi gün beyinlerden vibratom ile $50 \mu \mathrm{m}$ 'lik koronal kesitler alınd. Hipotalamusun rostro-kaudal ekseninin tamamını içerecek şekilde alınan kesitler, 5 seri halinde tampon solüsyon içerisine toplandı. Tampon solüsyonunda yıkanarak fiksatiften arındırılan kesitler antifriz madde içerisinde $-20^{\circ} \mathrm{C}$ 'de saklandi.

Oksitosin nöronlarında kainat reseptör alt birimleri ikili immünofloresan yöntemi ile belirlendi. Bu amaçla kesitler $-20^{\circ} \mathrm{C}$ 'den oda sıcaklığına çıkartıldı ve antifiriz maddenin oda sıcaklığına düşmesi beklendi. Takiben kesitler antifiriz maddeden arındırılmak üzere tampon ile yıkandı. Çalışmanın tüm aşamalarında tampon madde olarak $0,05 \mathrm{M}$ Tris- $\mathrm{HCl}$ solüsyonu $(\mathrm{pH}$ 7,6) kullanıldı. İmmünohistokimyasal süreçlerden önce kesitlere antijenin yeniden kazanılması işlemi uygulandi. Bu işlemde kesitler $50 \mathrm{mM}$ trisodyum sitrat tamponu ( $\mathrm{pH} \mathrm{6)}$ içerisinde mikrodalga firında 600 W'da 90 saniye ışınlandı (son sıcaklık $80-83^{\circ} \mathrm{C}$ ). Kesitler daha sonra ayn solüsyonda $40-43^{\circ} \mathrm{C}$ 'ye soğuyuncaya kadar bekletildi. Tampon solüsyonda yıkanan kesitlere spesifik olmayan bağlanmayı azaltmak için bloklama tamponu uygulandı. Bu solüsyon, Tris- $\mathrm{HCl}$ tamponu içerisinde bloklayıcı ajan olarak \%10 normal at serumu, bakteri oluşumunu engellemek amaciyla $\% 0,1$ sodyum azid ve yüzey gerilimini azaltıp antikorların hücre içine geçişini kolaylaştırmak için $\% 0,2$ Triton-X 100 içerecek şekilde hazırlandı. Tüm ikincil antikorların eşekte üretilmiş olması göz önünde bulundurularak bloklayıcı ajan olarak normal at serumunu seçildi. Çalışmada kullanılan tüm birincil ve ikincil antikorlar bloklama tamponu içerisinde sulandırılarak uygulandı. Bloklama işlemini birincil antikor inkübasyonu takip etti. Bu aşamada kobay anti-oksitosin antikoru ile kainat reseptör alt birimlerinden birine ait antikoru içeren karışımda inkübasyon uygulandı. Çalışmalarda kullanılan birincil antikorlarla ilgili detaylı bilgi Tablo I'de verilmiștir. Birincil antikor inkübasyonunu takiben tamponda yıkanan kesitler floresan işaretli birincil antikorun üretildiği türe uygun ikincil antikor solüsyonuna alındı. Çalışmalarımızda Jackson Immunoresearch Laboratuvarları'ndan (West Grove, 


\section{Oksitosin Nöronlarında Kainat Reseptörleri}

PA) elde edilen ikincil antikorlar kullanıldı. Kulland1ğımız tüm antikorlar eşekte üretilmiştir. Bu antikorlar çoklu işaretleme çalışmaları için uygun antikorlardır. Antikorlar üretici firma tarafından afinite pürifikasyonu ile özgülleştirilmiş, türler arası reaksiyon açısından incelenmiş ve bu reaksiyonlar minimal düzeyde bulunmuştur. Floresan işaretlemelerde oksitosin için fluorescein (FITC), reseptör alt üniteleri için Teksas kırmızısı ile işaretli ikincil antikorlar kullanıldı. GluK3 incelemeleri için, konfokal mikroskopta daha güçlü sinyal elde etmek amacıyla biyotin işaretli ikincil antikor inkübasyonunu takiben, Cy5 florokromu ile işaretli streptoavidin kompleksi tercih edildi. Bu aşamadan sonra kesitler tamponda yıkanarak lamlara alındı ve karanlık ortamda kurutuldu. Hazırlanan preparatlar mikroskobik incelemeden hemen önce kapama materyali (ProLong AntiFade, Molecular Probes, Eugene, CA) ile kapatıldı.

Tablo I. Çalışmada kullanılan antikorların özellikleri

\begin{tabular}{|c|c|c|c|}
\hline Birincil Antikorlar & Dilüsyon & Marka & $\begin{array}{l}\text { Katalog numarası } \\
\text { Lot Numarası }\end{array}$ \\
\hline $\begin{array}{l}\text { Kobay anti-oksitosin } \\
(\lg G)\end{array}$ & $1: 2000$ & Peninsula Labs. & $\begin{array}{l}\text { GHC } 8152 \\
\text { Lot No: } 031089\end{array}$ \\
\hline Keçi anti-GluK1 (lgG) & $1: 1.000$ & $\begin{array}{l}\text { Santa Cruz } \\
\text { Biotechnology }\end{array}$ & $\begin{array}{l}\mathrm{N}-19 \\
\text { Lot No: D240 }\end{array}$ \\
\hline Keçi anti-GluK2 (lgG) & $1: 100$ & $\begin{array}{l}\text { Santa Cruz } \\
\text { Biotechnology }\end{array}$ & $\begin{array}{l}\text { C-18 } \\
\text { Lot No: A289 }\end{array}$ \\
\hline Keçi anti-GluK3 (lgG) & $1: 1000$ & $\begin{array}{l}\text { Santa Cruz } \\
\text { Biotechnology }\end{array}$ & $\begin{array}{l}\text { N-18 } \\
\text { Lot No: H180 }\end{array}$ \\
\hline $\begin{array}{l}\text { Tavşan anti-GluK5 } \\
\text { (lgG) }\end{array}$ & $1: 6000$ & $\begin{array}{l}\text { Jenens ve Eyigör } \\
\text { tarafından } \\
\text { üretilmiştir }\end{array}$ & $\begin{array}{l}\text { Antikor referans } \\
\text { numarası: R52-4 }\end{array}$ \\
\hline
\end{tabular}

Çalışma kapsamında yapılan işaretlemeler sonucu hazırlanan preparatlarda koronal beyin kesitleri Swanson'un sıçan beyin atlasının koordinatlarına göre incelendi ${ }^{33}$. İncelenen kesitler, oksitosin nöronlarının sıçan beyninde yerleşimi göz önünde tutularak SON için bregma $-0,5$ ile bregma $-1,33$ ve PVN için bregma 1,08 ile bregma $-1,78$ koordinatları arasından seçildi. Çalışma kapsamında gerçekleştirilen ikili işaretlemelere ait preparatlar Kentucky Üniversitesi Anatomi ve Nörobiyoloji Departmanı Görüntü Analiz Ünitesi'nde kurulu bulunan lazer taramalı konfokal mikroskobu kullanılarak incelendi. İncelemelerde, işaretleyici florokroma uygun dalga boyunda lazer kaynakları kullanıldı. Tüm lazer taramaları ardaşık tarama olarak gerçekleştirildi. Bu yöntemle lazerlerin her biri tek başına açılarak, aynı anda kullanıldığında doğabilecek florokromlar arası spesifik olmayan sinyal geçişimleri problemi ortadan kaldırılmış oldu. İncelenen alanlar dijital resimler olarak kaydedildi.

Preparatların incelenmesi, her denek için, yukarıda belirtilen koordinatlar arasında yer alan, birbirine eşit uzaklıktaki beș kesitte yapıldı. Oksitosin nöronlarında glutamat reseptör alt birimlerinin ekspresyonunun belirlendiği ikili floresan işaretli kesitlerden elde edilen resimler bilgisayar ortamında grid kullanılarak değerlendirildi. Bu aşamada iki araştırmacı tarafından incelenen kesitlerde yar1-kantitatif bir analiz gerçek- leştirildi. İncelenen preparatta oksitosin nöronlarının büyük çoğunluğu ilgili reseptörle ko-lokalize olduğu belirlenmişse “+++" skoru kullanıldı. Buna karşılık eğer bir kısım oksitosin nöronu reseptör proteinini eksprese ederken, diğer bir kısım nöronda reseptör immünoreaktivitesi görülmemişse, "++" skoru kullanıldı. Çok az sayıda ikili işaretlenme belirlendiyse skorlama "+" şeklinde gerçekleştirildi.

\section{Bulgular}

Supraoptik ve paraventriküler çekirdeklerde yer alan oksitosin nöronları incelendiğinde, bu nöronlarda GluK1 reseptörüne ait ekspresyon sinyali görülmedi. Yapılan ikili işaretlemeler GluK2 kainat reseptör alt birim proteininin oksitosin nöronlarınca sentezlendiğini ortaya çıkardı. Gerçekleştirilen yarı-kantitatif inceleme sonucunda SON'de ve PVN'de yer alan tüm oksitosin nöronlarının yaklaşık yarısının GluK2 proteinini eksprese ettiği belirlendi (Şekil 1). İkili işaretleme görülen bu nöronların SON ya da PVN'de belirli bir yerleşim motifi göstermediği, çekirdeklerin rostrokaudal ekseni boyunca dağınık olarak yer aldıkları gözlendi. Oksitosin ile yapılan ikili boyamalarda, GluK3 immünreaksiyonunun arttırılması amacıyla sadece lazer taramalı konfokal mikroskopta eksitasyonu belirlenebilen Cy5 fluorokromu kullanıldı. Birincil antikor, biyontinlenmiş ikincil antikor ile bağlandıktan sonra, kesitler biyotine çok yüksek afinitesi olan streptoavidinle konjuge edilmiş Cy5 ile inkübe edildiğinde, GluK3 sinyalinin biraz daha arttığı görüldü. Ancak preparatlar incelendiğinde PVN ve SON'de yer alan oksitosin nöronlarında GluK3 sinyali görülmedi. Oksitosin ve GluK5 reseptör proteinleri için yapılan ikili immünohistokimyasal boyama sonucunda hem SON hem de PVN'de yer alan oksitosin nöronlarının sayıca çok büyük bir kısmının aynı zamanda GluK5 proteini sentezledikleri belirlendi (Şekil 2). Sunulan çalışmada gerçekleştirilen yarı-kantitatif analizler Tablo II'de özetlenmiştir.
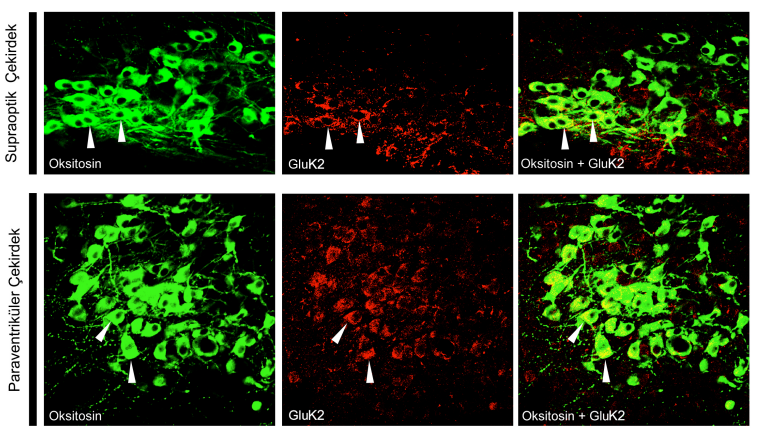

Sekil 1:

$S O N^{\prime} d e$ ve $P V N^{\prime}$ de oksitosin ve kainat reseptör alt ünitesi GluK2 proteini içeren nöronlarının konfokal lazer taramalı mikroskop ile elde edilen fotomikrograflart. GluK2 proteini eksprese eden oksitosin nöronların göstermektedir. 


\section{Z. Minbay ve Ö. Eyigör}

Tablo II. Kainat reseptör alt birimlerinin oksitosin nöronlarında ekspresyonu.

\begin{tabular}{|lcc|}
\hline Reseptör & Supraoptik Çekirdek & Paraventriküler Çekirdek \\
Alt birimi & - & - \\
\hline GluK1 & ++ & ++ \\
GluK2 & - & - \\
GluK3 & +++ & +++ \\
GluK5 & ++ & \\
\hline
\end{tabular}

“-": İkili işaraetlenen nöron yok. "+”: Çok az sayıda ikili işaretlenen nöron mevcut. "++": Nöronların yarıya yakını ikili işaretli, "+++": Çok sayıda ikili işaretlenen nöron mevcut.

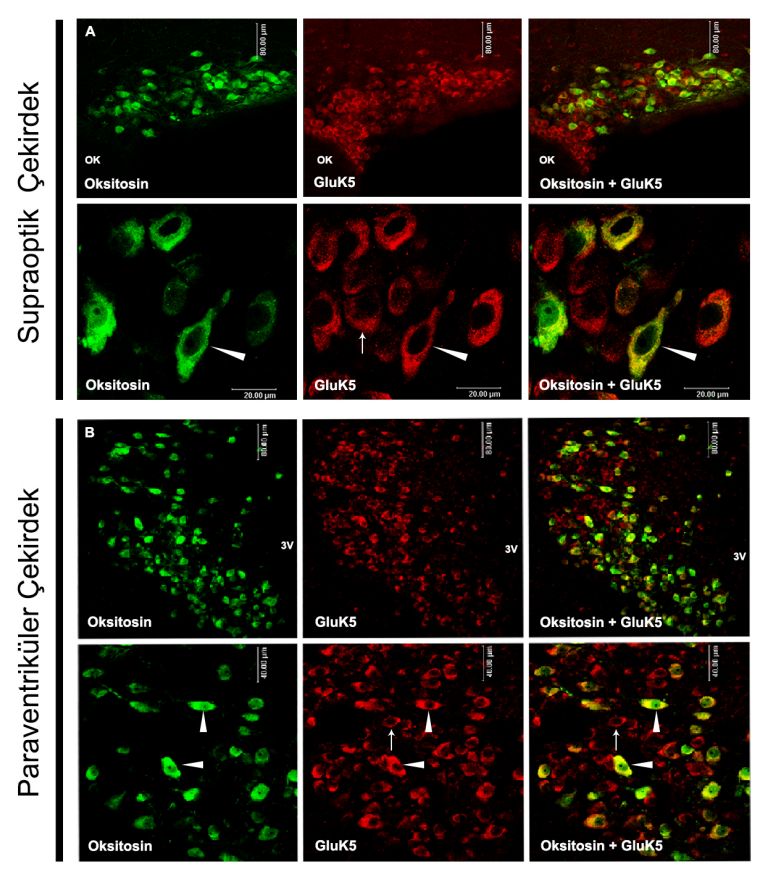

Sekil 2:

SON'de ve PVN'de oksitosin ve kainat reseptör alt ünitesi GluK5 proteini eksprese eden nöronlarının konfokal lazer taramalı mikroskop ile elde edilen fotomikrograflart. GluK5 proteini eksprese eden oksitosin nöronlarını, $\rightarrow$, sadece GluK5 immünopozitif nöronlarl göstermektedir.

\section{Tartışma ve Sonuç}

Çalışmamızın bulguları, oksitosin nöronlarının sıçan hipotalamusunda iki ana çekirdekte (SON ve PVN) yerleșik olduğunu gösterdi. Bu sonuçların, literatürde yapılmış olan çalışmaların ${ }^{5,34}$ bulgularına paralellik gösterdiği saptandı. İkili işaretlemelerin incelenmesinden önce hipotalamusta kainat reseptör alt birim proteinlerinin varlıkları ve dağılımları açısından preparatlar incelendiğinde, GluK1'in sınırlı bir dağılım gösterdiği, GluK2 ve GluK5'in ise hipotalamik alanlar ve çekirdeklerde yaygın olarak eksprese edildiği görüldü. Çalışmamızda GluK1-pozitif hücrelerin, GluK1
mRNA dağılım paterninin belirlendiği çalışmaların bulgularıyla ${ }^{35,36}$ benzer bir hipotalamik yerleşim gösterdikleri izlendi. Oksitosin nöronları açısından değerlendirildiğinde ise, yaptığımız ikili işaretleme çalışmaları sonucunda SON'de GluK1 immünreaktif hücrelerin bulunmaması ve PVN'de çok küçük bir grup oluşturan GluK1-pozitif hücrelerin oksitosin-negatif olmas1 nedeniyle bu alt birimin oksitosin nöronlarında sentezlenmediği düşünüldü. GluK2 ve GluK5 alt birim proteinlerinin hipotalamusta yerleşik hücre gruplarındaki dağılım paterninin, literatürde yer alan raporları desteklediği belirlendi ${ }^{37}$. Bu dağılım mRNA ekspresyonu ile de aynı doğrultuda olduğu görüldü ${ }^{35,36,38}$. Çalışmamızda oksitosin sentez ve salgılanmasından sorumlu olan nöronların bulunduğu supraoptik ve paraventriküler çekirdeklerde, yoğun GluK2 ve GluK5 protein ekspresyonu belirlenmiştir ve bu bulgu Petralia ve ark'nın raporlarını desteklemektedir ${ }^{37}$. GluK2 ve GluK5 proteinlerinin SON ve PVN nöronlarının çoğunda eksprese olduğu ve yaptığımız ikili işaretleme sonucunda çok sayıda oksitosin nöronunun bu alt birimleri eksprese ettiği görüldü. GluK3 immünoreaktivitesinin GluK3 mRNA ekspresyonu görülmeyen ${ }^{35,38}$ SON ve PVN'de belirlenmesi beklenilmeyen bir sonuçtur. Bu farklılığın, çalışmalarda in situ hibridizasyon ve immünohistokimya gibi iki farklı yöntemin kullanılmış olmasından kaynaklanabileceği düşünüldü. Ancak bulgular kısmında da belirtildiği gibi GluK3 ekspresyonuna SON ve PVN'de yer alan oksitosin nöronlarında rastlanmadi.

Glutamat reseptör alt birim proteinlerinin oksitosin nöronlarında belirlenmesi amacıyla yapılan immünohistokimyasal çalışmalar göreceli olarak azdır. Curras-Collazo ve arkadaşları ${ }^{32}$, oksitosin nöronlarının NMDA reseptör alt birimi olan GluN2B proteinini eksprese ettiklerini göstermişlerdir. Literatürde AMPA/kainat reseptörlerinin oksitosin nöronlarında ekspresyonunun immünohistokimyasal olarak arașt1rıldığı çalışma sayısı da çok azdır. Primatlarda yapılan bir çalışmada AMPA reseptör alt birimlerinden GluA3'ün oksitosin nöronlarında eksprese edildiği hem 1 şı hem de elektron mikroskopik düzeyde gösterilmiștir $^{31}$. Bilgimiz dahilinde çalışmamız, literatürde oksitosin nöronlarında kainat reseptör protein sentezinin belirlenmesinin amaçlandığı ve gösterildiği ilk çalışmadır.

Merkezi sinir sisteminde yer alan eksitatör ve inhibitör nörotransmitterlerin, süt ejeksiyonu ve doğum sırasında oksitosin sentez ve salgısı üzerine etkileri olduğu bilinmektedir $^{1,3,39}$. Oksitosin metabolizmasinda yer alan en önemli eksitatör nörotransmitter glutamattır ${ }^{13}$. Doğumda ilk 15 dakikada supraoptik çekirdek glutamat konsantrasyonunda anlamlı bir artma görülmüştür $^{40}$. SON ve PVN'de lokal eksitatör sinaptik oluşumların varlığı özellikle elektofizyolojik çalıșmalarla belirlenmiştir. Boudaba ve arkadaşları ${ }^{41}$, glutamat mikrostimülasyonu ile SON ve PVN nöronlarında 


\section{Oksitosin Nöronlarında Kainat Reseptörleri}

eksitatör postsinaptik potansiyasyon belirlemişlerdir $\mathrm{Bu}$ etki iyonotropik glutamat reseptör antagonistleri ile bloke edilebilmiştir. Stern ve arkadaşları ${ }^{22}$, yaptıkları elektrofizyolojik çalışmalarda SON nöronlarında NMDA ve non-NMDA reseptörlerinin aktivasyonunun farklı etkiler gösterdiğini belirlemişlerdir. SON ve PVN'de yer alan nöronların dörtte birinin glutamat içeren sinapslarla kontakt yaptığ 1 bildirilmiştir ${ }^{19,42}$ SON'de oksitosin nöronları üzerindeki sinapsların \%20'si glutamaterjikken, laktasyon gibi fizyolojik oksitosin sentez ve salınımının yoğunlaştığı koşullarda bu oranın arttığ1 görülmüştür ${ }^{43,44}$. Bu bilgiler 1şı̆̆ında, glutamaterjik sistemin oksitosin nöronlarını direkt olarak etkileyebileceği kainat reseptörlerinin oksitosin nöronlarında var olduğunun bu çalışmada gösterilmesi önemli bir bulgudur.

Fonksiyonel glutamat reseptörleri, alt ailelere ait alt birimlerin homomerik ve/veya heteromerik dizilimleri ile iyon kanalları şeklinde oluşurlar. NMDA reseptörleri sadece kendi alt birimlerinin yer aldığı fonksiyonel kanallar oluştururken, AMPA ve kainat reseptör alt birimlerinin kendi aralarında heteromerik reseptör kanalları oluşturdukları belirlenmiştir ${ }^{18}$. Kainat reseptör alt birimlerinden GluK5'in homomerik kanal oluşturmadığ1, ancak GluK1, GluK2 ve GluK4 ile birlikte eksprese edildiğinde fonksiyonel iyon kanalı yaptığ farmakolojik çalışmalarda belirlenmiştir ${ }^{18,45}$. Çalışmamızın sonuçlarının oksitosin nöronlarında GluK2 ve GluK5 alt birimlerinin sentezlendiğini göstermesi, oksitosin nöronlarında fonksiyonel olarak aktif kainat-seçici glutamat reseptör kanallarının oluşabileceğini düşündürmektedir.

Reseptör bağlama çalışmaları SON ve PVN nöronlarının radyoaktif glutamata afinite gösterdiğini belirlemiştir. SON'de yapılan bir çalışmada, radyoaktif glutamatın daha çok non-NMDA reseptörlerine bağland1ğ1, bağlanma oranının NMDA reseptörlerinde daha düşük, metabotropik reseptörlerde ise en az seviyede olduğu gösterilmiştir ${ }^{46}$. Magnosellüler hücrelerde glutamaterjik iletinin oluştuğunu gösteren ilk çalışmalarda, AMPA reseptörlerinin önemli bir rol aldığ belirlenmiştir ${ }^{47}$. Young ve arkadaşları ${ }^{48}$, magnosellüler nöronların glutamaterjik etkileniminde AMPA reseptörlerine ek olarak NMDA reseptörlerinin de rol ald1ğını göstermiştir. Elektrofizyolojik çalışmalar, supraoptik çekirdek nöronlarında glutamaterjik etkinin algılanmasında kainat reseptörlerinin rolü olduğunu ortaya koymuştur ${ }^{49}$. Oksitosin nöronlarının, vazopressin nöronlarının aksine kainik asite yanıt olarak spontane deşarj gösterdikleri ve bu deşarjların CNQX ile bloke edilebildiği bildirilmektedir ${ }^{25,50,51}$. Bu da oksitosin nöronlarına glutamaterjik etkinin iletilmesinde non-NMDA reseptörlerinin esas rol oynadığını göstermektedir. Laboratuvarımızda gerçekleştirilen çalışmada özellikle kainat reseptörleri üzerinden etkili olduğu bilinen kainik asidin oksitosin nöronlarında aktivasyona neden olduğu ve bu aktivasyonun gluta- mat antagonisti CNQX ile bloklanabildiği gösterilmiştir $^{21}$. Yukarıda sunulan çalışma sonuçları da bu bulguyu destekleyecek şekilde oksitosin nöronlarının glutamatın etki gösterebileceği fonksiyonel iyon kanalı oluşturabilecek kainat reseptör alt birimlerinden GluK2 ve GluK5'i sentezlediğini göstermiştir.

Sonuç olarak, çalışmamızda oksitosin nöronlarının fonksiyonel reseptör kanalı oluşturabilecek kainat reseptör alt birimlere ait proteinleri eksprese ettiklerinin belirlenmesi, endojen glutamatın oksitosin nöronları üzerindeki etkilerini bu reseptörlere bağlanarak gerçekleştirebileceğini düşündürmektedir. Her ne kadar bu bulgular oksitosin nöronlarının foksiyonlarının düzenleniminde kainat reseptörlerinin rolü olduğunu doğrudan göstermese de oksitosin nöronlarında kainat reseptör alt birimlerinin ekspresyonun gösterilmesi bu konudaki literatüre önemli katkılar sağlayacağı düşüncesindeyiz. Literatürde yer alan ve gelecekte yapılacak olan fizyolojik ve farmakolojik çalışmalarla veya transgenik hayvanlardan elde edilebilecek bulgulara çalışmamızda elde ettiğimiz sonuçlar eklendiğinde, kainat reseptörlerinin oksitosin sentez ve salgılama mekanizmasındaki rolü açıklığa kavuşacaktir.

\section{Teşekkür}

Bu çalışma TÜBİTAK tarafindan desteklenmiştir (101S058 [SBAG-2459]). GluK5 antikoru için Prof Dr. Lothar JENNES'e (University of Kentucky) ve lazer taramalı konfokal mikroskop kullanımımızı sağlayan Kentucky Üniversitesi Görüntüleme Ünitesi sorumlusu Prof. Dr. Bruce MALEY'e teşekkür ederiz.

Etik Kurul Onay Bilgisi:

Onaylayan Kurul: Uludağ Üniversitesi Hayvan Bakım ve Kullanım Komitesi.

Onay Tarihi: 19.04 .2005

Karar No: 19.04.2005/1

\section{Kaynaklar}

1. Challis JRG, Lye SJ. Parturition. In: The physiology of reproduction. Knobil E, Neill JD (eds). New York: Raven Press;1994. 985-1031.

2. Higuchi T, Okere CO. Role of Supraoptic nucleus in regulation of parturition and milk ejection revisited. Microsc Res Tech 2002;56:113-121.

3. Wakerley JB, Clarke G, Summerlee AJ. Milk ejection and its control. In: The physiology of reproduction. Knobil E, Neill JD (eds). New York: Raven Press; 1994. 1131-1177.

4. Gainer H, Wray S. Cellular and molecular biology of oxytocin and vasopressin. In: The physiology of reproduction. Knobil E, Neill JD (eds). New York: Raven Press; 1994.1099-1129.

5. Hatton GI. Emerging concepts of structure-function dynamics in adult brain: the hypothalamo-neurohypophysial system. Prog Neurobiol 1990;34:437-504. 


\section{Z. Minbay ve Ö. Eyigör}

6. Hollmann M, Heinemann S. Cloned glutamate receptors. Ann Rev Neurosci 1994;17:31-108.

7. Daftary SS, Boudaba C, Szabó K, Tasker JG. Noradrenergic excitation of magnocellular neurons in the rat hypothalamic paraventricular nucleus via intranuclear glutamatergic circuits. J Neurosci 1998;18:10619-10628.

8. Bealer SL, Crowley WR. Stimulation of central and systemic oxytocin release by histamine in the paraventricular hypothalamic nucleus: Evidence for an interaction with norepinephrine, Endocrinology 1999;140:1158-1164.

9. Gribkoff VK. Electrophysiological evidence for N-methyl-Daspartate excitatory amino acid receptors in the rat supraoptic nucleus in vitro. Neurosci Lett 1991;131:260-262.

10. Inenaga K, Honda E, Hirakawa T, Nakamura S, Yamashita H. Glutamatergic synaptic inputs to mouse supraoptic neurons in calcium-free medium in vitro. J Neuroendocrinol, 1998;10:1-7.

11. Meeker RB, Greenwood RS, Hayward JN. Glutamate is the major excitatory transmitter in the supraoptic nuclei. Ann NY Acad Sci 1993;22: 636-639.

12. Van Den Pol AN, Trombley PQ. Glutamate neurons in hypothalamus regulate excitatory transmission. J Neurosci 1993;13:2829-2836

13. Van Den Pol AN, Wuarin JP, Dudek F.E. Glutamate neurotransmission in the neuroendocrine hypothalamus. In: Excitatory Amino Acids The Role in Neuroendocrine Function. Brann DW, Mahesh B, (eds). Boca Raton: CRC Press; 1996. 1-54.

14. Voisin DL, Herbison AE, Chapman C, Poulain DA. Effects of central $\mathrm{GABA}_{\mathrm{B}}$ receptor modulation upon the milk ejection reflex in the rat. Neuroendocrinology 1996;63:368-376.

15. Brann DW. Glutamate: A major excitatory transmitter in neuroendocrine regulation. Neuroendocrinology 1995;61:213-225.

16. Brann DW, Mahesh VB. Excitatory amino acids: Function and significance in reproduction and neuroendocrine regulation. Front Neuroendocrinol 1994;15:3-49.

17. Seeburg PH. The molecular biology of mammalian glutamate receptor channels. Trends Neurosci 1993;16:359-365.

18. Bettler B, Mulle C. Review: neurotransmitter receptors II. AMPA and kainate receptors. Neuropharmacology 1995;34: 123-139.

19. Meeker RB, Swanson DJ, Greenwood RS, Hayward JN. Quantitative mapping of glutamate presynaptic terminals in the supraoptic nucleus and surrounding hypothalamus. Brain Res 1993;600:112-122.

20. Jourdain P, Dupouy B, Bonhomme R, Theodosis DT, Poulain DA, Israel JM. Electrophysiological studies of oxytocin neurons in organotypic slice cultures. Adv Exp Med Biol 1998;449:135-145.

21. Minbay FZ, Eyigor O, Cavusoğlu I. Kainic acid activates oxytocinergic neurons through non-nmda glutamate receptors. Int J Neurosci 2006;116:587-600.

22. Stern JE, Galarreta M, Foehring RC, Hestrin S, Armstrong WE Differences in the properties of ionotropic glutamate synaptic currents in oxytocin and vasopressin neuroendocrine neurons. J Neurosci 1999;19:2267-3375.

23. Parker SL, Crowley WR. Central stimulation of oxytocin release in the lactating rat by N-methyl-D-aspartate: Requirement for coactivation through non-NMDA glutamate receptors or the glycine coagonist site. Neuroendocrinology 1995;62:467478.

24. Parker SL, Crowley WR. Stimulation of oxytocin release in the lactating rat by central excitatory amino acid mechanisms: evidence for specific involvement of R,S- $\alpha$-amino-3-hydroxy-5methylisoxazole-4-propionic acid-sensitive glutamate receptors. Endocrinology 1993;133:2847-2854.

25. Jourdain P, Israel JM, Dupouy B, Oliet SH, Allard M, Vitiello S, Theodosis DT, Poulain DA. Evidence for a hypothalamic oxytocin-sensitive pattern-generating network governing oxytocin neurons in vitro. J Neurosci 1998;18:6641-6649.

26. Olazabal DE, Ferreira A. Maternal behavior in rats with kainic acid-induced lesions of the hypothalamic paraventricular nucleus. Physiol Behav 1997;61:779-784.

27. Richardson CM, Wakerley JB. Glutamate excitation of oxytocin neurons in vitro involves predominantly non-NMDA receptors. Brain Res 1997;767:158-161.

28. Yagi K, Onaka T, Yoshida A. Role of N-methyl-D-aspartate (NMDA) receptors in vasopressin and oxytocin responses to emotional stimuli. Adv Exp Med Biol 1998;449:131-134.

29. Israel JM, Poulain DA. 17-Oestradiol modulates in vitro electrical properties and responses to kainate of oxytocin neurones in lactating rats. J Physiol (Lond) 2000;15:457-470.

30. Sun Q, Pretel S, Applegate CD, Piekut DT. Oxytocin and vasopressin mRNA expression in rat hypothalamus following kainic acid-induced seizures. Neuroscience 1996;71:543-554.

31. Ginsberg SD, Price DL, Blackstone CD, Huganir RL, Martin LJ. The AMPA glutamate receptor GluR3 is enriched in oxytocinergic magnocellular neurons and is localized at synapses. Neuroscience 1995;65:563-575.

32. Curras-Collazo MC, Chin C, Diaz G, Stivers C, Bozzetti L, Tran LY. Immunolabeling reveals cellular localization of the $\mathrm{N}$-methyl-D-aspartate receptor subunit NR2B in neurosecretory cells but not astrocytes of the rat magnocellular nuclei. J Comp Neurol 2000;427:93-108.

33. Swanson LW. Brain Maps: Structure of the rat brain. Amsterdam: Elsevier; 1998.

34. Jirikowski GF, Caldwell JD, Pikgrim C, Stumpf WE, Pedersen CA. Changes in immunostaining for oxytosin in the forebrain of the female rat during late pregnancy, parturition and early lactation. Cell Tissue Res 1980;256:411-417.

35. Eyigor O, Centers A, Jennes L. Distribution of ionotropic glutamate receptor subunit mRNAs in the rat hypothalamus. J Comp Neurol 2001;434:101-124.

36. Herman JP, Eyigor O, Ziegler DR, Jennes L. Expression of ionotropic glutamate receptor subunit mRNAs in the hypothalamic paraventricular nucleus of the rat. J Comp Neurol 2000;422:352-362.

37. Petrelia RS, Wang YX, Wenthold RJ. Histological and ultrastructural localization of the kainate receptor subunits, KA2 and GluR6/7, in the rat nervous system using selective antipeptide antibodies. J Comp Neurol 1994;349:85-110.

38. Van Den Pol AN, Hermans-Borgmeyer I, Hofer M, Ghosh P, Heinemann S. Ionotropic glutamate-receptor gene expression in hypothalamus: Localization of AMPA, kainate, and NMDA receptor RNA with in situ hybridization. J Comp Neurol 1994;343:428-444.

39. Crowley WR, Armstrong WE. Neurochemical regulation of oxytocin secretion in lactation. Endocr Rev 1992;13:33-65.

40. Pak CW, Curras-Collazo MC. Expression and plasticity of glutamate receptors in the supraoptic nucleus of hypothalamus. Microsc Res Tech 2002;56:92-100.

41. Boudaba C, Schrader LA, Tasker JG. Physiological evidence for local excitatory synaptic circuits in the rat hypothalamus. J Neurophysiol 1997;77:3396-3400.

42. Van Den Pol AN, Wuarin JP, Dudek FE. Glutamate, the dominant excitatory transmitter in neuroendocrine regulation. Science 1990;250:1276-1278.

43. El Majdoubi M, Poulain DA, Theodosis DT. The glutamatergic innervation of oxytocin- and vasopressin-secreting neurons in the rat supraoptic nucleus and its contribution to lactationinduced synaptic plasticity. Eur J Neurosci 1996;8:1377-1389.

44. Theodosis DT, El Majdoubi M, Gies U, Poulain DA. Physiologically-linked structural plasticity of inhibitory and excitatory synaptic inputs to oxytocin neurons. Adv Exp Med Biol 1995:395:155-171. 


\section{Oksitosin Nöronlarında Kainat Reseptörleri}

45. Cui C, Mayer ML. Heteromeric kainate receptors formed by coassembly of GluR5, GluR6, and GluR7. J Neurosci 1999;19:8281-8291.

46. Meeker RB, Greenwood RS, Hayward JN. Glutamate receptors in the rat hypothalamus and pituitary. Endocrinology 1994;134:621-629.

47. Wuarin JP, Dudek FE. Patch-clamp analysis of spontaneous synaptic currents in supraoptic neuroendocrine cells of the rat hypothalamus. J Neurosci 1993;13:2323-2331.

48. Yang QZ, Smithson KG, Hatton GI. NMDA and non-NMDA receptors on rat supraoptic nucleus neurons activated monosynaptically by olfactory afferents. Brain Res 1995;680:207216.
49. Gribkoff VK, Dudek FE. Effects of excitatory amino acid antagonists on synaptic responses of supraoptic neurons in slices of rat hypothalamus. J Neurophysiol 1990;63:60-71.

50. Nissen R, Hu B, Renaud LP. N-methyl-D-aspartate receptor antagonist ketamine selectively attenuates spontaneous phasic activity of supraoptic vasopressin neurons in vivo. Neuroscience 1994;59:115-120.

51. Nissen R, Hu B, Renaud LP. Regulation of spontaneous phasic firing of rat supraoptic vasopressin neurons in vivo by glutamate receptors. J Physiol 1995;484:415-424. 
